\section{Memorial ceremony} to be held

\section{Munich}

The West German Max Planck Society (MPS) last week set 25 May as the date for a memorial ceremony to Nazi euthanasia victims whose brains had been used for research purposes by the Kaiser Wilhelm Society, the forerunner of MPS. Officials from the local Jewish community as well as Catholics and Protestants will be invited to take part, said MPS official Peter GutjahrLöser, although Jews were not believed to have been among the victims.

MPS last year removed thousands of brain tissue samples from its collections at three institutes in Frankfurt, Cologne and Munich and quietly buried them at a cemetery in Munich in February. Some of the samples belonged to the infamous Hallervorden collection (see Nature 339, 498; 1989).

Some scientists in Canada and the United States earlier this month called for a worldwide moment of silence and the broad participation of medical researchers in a ceremony commemorating the victims, but MPS chose a quieter route because it did not feel that it alone should be publicly associated with crimes that took place during the Nazi era. Gutjahr-Löser supported the suggestion by Wolf Singer, director of the Max Planck Institute for Brain Research in Frankfurt, that researchers' complicity in such crimes should instead be discussed at a workshop of the International Brain Research Organization, of which Singer is a member.

Even the memorial ceremony has been kept quiet in West Germany, says GutjahrLöser, in order to avoid disruptions and allow the ceremony to proceed in a "dignified" manner. Other public occasions with a connection to the Nazi period, such as the 1987 funeral of Nazi war criminal Rudolf Hess, drew much unwanted interest from neo-Nazi groups. The time and place of the Hess funeral was kept secret, but this did not prevent neo-Nazi outbursts at the place where he was expected to be buried.

The samples would have been buried and the ceremony held sooner, said GutjahrLöser, but a Frankfurt university professor involved in the decision (who is not a member of MPS) questioned the propriety of burying samples whose origins were unknown. Nevertheless, MPS decided to bury any sample where there was any question of its having derived from a euthanasia victim.

The text of the inscription carved on the stone at the memorial will read: "In remembrance of the victims of National Socialism and their abuse by medical science. To all researchers an exhortation to set their own boundaries in a responsible manner."

\title{
US to end modernization
}

\section{Boston}

THE Bush administration has offered to end the United States' chemical weapons modernization programme in exchange for several Soviet concessions, according to officials inside and outside the Bush administration. The possible reversal of a programme that the administration had supported steadfastly was uncovered by the press last week, but is said to have been proposed during Soviet Foreign Minister Eduard A. Shevardnadze's visit to Washington last month.

State Department officials formally acknowledge only that a "range of possibilities" concerning chemical weapons are being discussed with the Soviets. But a number of inside observers express confidence that a bilateral agreement will come soon, perhaps during the summit between Presidents George Bush and Mikhail Gorbachev planned for the end of this month in Washington. In this agreement, they say, the United States is likely to abandon its programme to modernize binary chemical weapons. Binary weapons, which produce a lethal substance only when two separately stored chemicals are mixed, are more stable in storage than the older poison-gas weapons.

In particular, the United States is said to have offered to stop production of new binary chemical weapons in exchange for a firm and speedy timetable for the destruction of current chemical stocks and an agreement on the contentious issue of whether the United States can, as the administration desires, retain two per cent of its chemical weapons stockpile as a deterrent against nations that do not sign a global treaty banning the weapons. The Soviets have maintained until now that no such stockpiles should be allowed.

Critics of the administration say that the move to abandon the production of binary weapons has come only because of technical and political problems that are besetting the modernization programme. Recently, for instance, two US-based companies refused to provide an essential ingredient for one of the proposed chemical weapons (see Nature 344, 802; 26 April 1990). In this sense, critics say, Bush is merely trying to turn a faltering programme into a diplomatic bargaining counter.

Elisa Harris, a senior research analyst at the Brookings Institution in Washington, admits that the beleaguered state of the modernization programme "may have helped to tip the balance" toward the latest US proposal, but argues that the administration "deserves credit" for taking stock of a changed situation and a substantially changed "chemical threat" from the Warsaw pact.

Harris and others say that a bilateral US-Soviet agreement will give an important boost to multilateral talks and "remove lingering doubts in Geneva" about the US commitment to a global ban on chemical weapons.
Seth Shulman

\section{International treaty made domestic law}

\section{Boston}

FIFTEEN years after the US Senate ratified the Biological Weapons Convention of 1972, an international treaty that bans the development, stockpiling and use of biological weapons, the Congress finally approved last week a bill that renders the provisions of the international treaty into domestic law. The bill prohibits any individual from knowingly producing or possessing any biological agent for use as a weapon. As in the international treaty, biological research on toxins or biological agents that is conducted for peaceful purposes is exempted.

Although the bill was approved unanimously, its passage comes only after several failed attempts over the past few years. The new legislation is seen as a victory for scientists and officials who have denounced stepped-up military interest, in the United States and abroad, in biological agents. In response to a fourfold increase in US military support for biological research, more than a thousand biomedical researchers have pledged in the past two years not to engage knowingly in research that would further the development of chemical or biological arms (see Nature 334,$279 ; 1988$ ). Many of these researchers have argued that the United States' failure to adopt a domestic law specifically banning the production of biological weapons undercut its formal support for the treaty.

Jonathan King, a biologist at the Massachusetts Institute of Technology who sponsored the pledge campaign on behalf of the Council for Responsible Genetics, called the legislation's passage "a very important step" in "ensuring that biotechnology is developed for peaceful means" and says it provides an important "enforcement tool" against research that may violate "the spirit, if not the letter" of the treaty. He also says that the legislation's timing is important because a treaty review conference is scheduled for next year. The congressional action, he says, may help build a climate in which signatory nations can work for strengthened treaty verification measures. Seth Shulman 